\title{
Chitosan Reduces Infection by Guignardia citricarpa in Postharvest 'Valencia' Oranges
}

\author{
Maria Cristina Canale Rappussi ${ }^{1}$, Sérgio Florentino Pascholati $^{1 *}$, Eliane Aparecida Benato ${ }^{2}$ \\ and Patrícia $\mathrm{Cia}^{3}$ \\ ${ }^{I}$ Departamento de Entomologia; Fitopatologia e Zoologia Agrícola; Escola Superior de Agricultura "Luiz de \\ Queiroz”; C. P.: 9; 13418-900; Piracicaba - SP - Brasil. ${ }^{2}$ Grupo de Engenharia Pós-Colheita; Instituto de \\ Tecnologia de Alimentos; C. P.: 139; 13070-178; Campinas - SP - Brasil. ${ }^{3}$ Instituto Agronômico; Centro de \\ Engenharia e Automação; C. P.: 26; 13201-970; Jundiaí - SP - Brasil
}

\begin{abstract}
Citrus fruits are affected by the black spot disease caused by Guignardia citricarpa. Resistance induction is an alternative control measure and chitosan exhibits potential as resistance inducer. The effect of chitosan on $\mathrm{G}$. citricarpa was evaluated in vitro and in 'Valencia' oranges. Citrus fruit were immersed into different chitosan concentrations. Chitosan (2\%), combined with or without thiabendazole and the citric acid was also investigated. All the chitosan concentrations inhibited G. citricarpa mycelial growth and affected morphologically the conidial germination and appressorium formation. Chitosan inhibited the development of new lesions in oranges at room condition or under refrigeration. Thiabendazole and citric acid did not reduce the formation of lesions. Biochemical analysis revealed that chitinase, $\beta$-1,3-glucanase, peroxidase and polyphenoloxidase activities were increased in chitosan-treated fruits. Thus, the effect of chitosan on the reduction of black spots in 'Valencia' oranges could be due to the germicidal effect on the pathogen and/or resistance induction in the fruit.
\end{abstract}

Key words: Black spot, citrus fruit, alternative control, resistance induction

\section{INTRODUCTION}

Orange is one of the most important worldwide commercialised fruit. This crop faces several phytosanitary problems, which include the citrus black spot, disease caused by Guignardia citricarpa Kiely, occurring in Africa, Asia, Australia and South America (Argentina, Brazil and Peru) (Reis et al., 2006). It is considered an A1 quarentenary disease in Europe Union that limits the citrus export. The lesions on the fruits restrict to the skin (flavedo), not reaching the albedo, and harm the fruits appearance making unfeasible their commercialisation at the fresh fruit market. Six different types of symptoms are described: false melanose, hard spot, black spot, freckled spot, virulent spot, and crunched spot (Góes, 2001).

This disease is controlled in field by fungicidal spraying. On postharvest, benzimidazole and imazalil are used for the disease control (Fischer et al., 2004). However, the problems caused by diseases have been maximized by the development of pathogen resistance to fungicides and by the withdrawal of some products from the market. Consequently, alternative control strategies, such as natural compounds that can also induce the resistance responses in the fruits have drawn attention. During the development of

\footnotetext{
* Author for correspondence: sfpascho@esalq.usp.br
} 
commercially valuable plant organs and after their harvest, natural disease resistance (NDR) generally declines leading to infection, disease and death. In horticultural products, postharvest diseases caused by fungi usually begin as either latent infections established in the field or wound infections during subsequent harvesting and handling. A decline in NDR can activate quiescent infections and increase disease incidence/severity (Terry and Joyce, 2004).

Vegetable tissues can show structural and biochemical mechanisms that can contribute for their resistance against the pathogens (Pascholati and Leite, 1995) and the activation of latent mechanisms of resistance can occur by the action of biotic or abiotic agents (Hammerschmidt and Dann, 1997). Resistance induction can be manifested as a hypersensitive response that results in cell death at the penetration site, structural alteration, accumulation of reactive oxygen species, synthesis of secondary metabolites and production of a range of defence molecules ("pathogenesis related proteins" or PRproteins) (Van-Loon and Van-Strien, 1999).

Chitosan is a chitin deacetilated polymer, soluble in organic acids that can be used as fruit covering and has potential as resistance inducer. Microscopic observations indicate that chitosan has a direct effect on the morphology of the microorganism showing the fungistatic or fungicidal potential. In addition to direct microbial activity, studies strongly suggest that chitosan induces a series of defence reactions correlated with enzyme activities (Bautista-Bañoz et al., 2003).

Chitosan application significantly reduced Botrytis cinerea rot in strawberries (El Ghaouth et al., 1992) and in grapes (Camili, 2004). El Ghaouth et al. (1994) reported that while in inoculated control tissues of bell pepper fruit, invading hyphae appeared normal, the fungal cells detected in chitosan-treated tissue displayed various degrees of cellular disorganization from wall loosening to protoplasm degradation. Structural host defence responses such as formation of wall appositions and plugging of intercellular spaces with fibrillar material were observed in chitosan-treated tissues. The objective of this work was to evaluate the in vitro effects of chitosan on the mycelial growth, germination and apressorium formation of $G$. citricarpa and in controlling the black spot on postharvest 'Valencia' oranges. Biochemical defence mechanisms in the plant tissue were also investigated $(\beta$-1,3-glucanase, $\quad$ chitinase, peroxidase and polyphenoloxidase).

\section{MATERIAL AND METHODS}

\section{Pathogen}

The pathogen G. citricarpa was isolated from the hard spots lesions of oranges harvested in orchards at Mogi Guaçu and Casa Branca, São Paulo State. Cultures were maintained on potato-dextrose agar (PDA) in Petri dishes at $25^{\circ} \mathrm{C}$ for in vitro assays.

\section{In vitro effect of chitosan on $G$. citricarpa development}

The effect of chitosan on the mycelial growth of $G$. citricarpa was evaluated by transferring mycelium discs ( $3 \mathrm{~mm}$ of diameter) to the centre of PDA medium plates having different concentrations of the product $(0.5,1.0,1.5,2.0$, and $3.0 \%$ ). The chitosan was supplied by Cyrbe Ltda (Sumaré, São Paulo State), in the concentration of $10 \%$ diluted in citric acid. The plates were maintained at $25^{\circ} \mathrm{C}$ for 21 days $(12 \mathrm{~h}$ photoperiod) and colony diameter was evaluated every 3 days. The effect of chitosan $(1 \%)$, citric acid (2\%, purchased from Dinâmica Química) and thiabendazole $\left(200 \mu \mathrm{L} \mathrm{L}^{-1}\right)$ was also evaluated on the mycelial growth. The experimental design was completely randomised with five replications (one plate per set).

Conidial germination and appressorium formation were checked by using ELISA plates. Droplets represented by $40 \mu \mathrm{L}$ of chitosan and $40 \mu \mathrm{L}$ of conidial suspension $\left(10^{5}\right.$ conidia $\left.\mathrm{mL}^{-1}\right)$ were deposited inside each well of the plate. Distilled water was used as control. The plate was maintained at $25^{\circ} \mathrm{C}$ for $24 \mathrm{~h}$ and evaluation was carried out by counting 100 conidia per well. The experimental design was completely randomised with eight replications (one well per set).

\section{In vivo effect of chitosan in controlling the black spot}

'Valencia' oranges produced in Mogi Guaçu, São Paulo State were washed with water plus detergent and after that surface-sterilized with sodium hypochlorite $\left(200 \mathrm{mg} \mathrm{L}^{-1}\right)$ for $10 \mathrm{~min}$. All the spots on the citrus naturally infected were marked with a pen before treatments. Chitosan was supplied by Cyrbe Ltda (Sumaré, São Paulo State) in the concentration of $10 \%$, diluted in citric acid. Citrus 
fruits were immersed into the chitosan solutions $(0.5,1.0,1.5,2.0$, and $3.0 \%, \mathrm{v} / \mathrm{v})$ and stored at $25^{\circ} \mathrm{C} \pm 11^{\circ} \mathrm{C} / 75-85 \% \mathrm{RH}$ in cardboard boxes. The evaluations were carried out after 2, 6 and 8 days of storage by counting the number of new lesions on fruit skin, that appeared during storage period. The experimental design was completely randomised with 40 fruits per treatment. Regression analysis was performed.

Another assay was carried out to evaluate the effect of thiabendazole (480 g a.i. $\left.100 \mathrm{~L}^{-1}\right)$, chitosan (2\%), and both thiabendazole plus chitosan. Fruits were stored at $25^{\circ} \mathrm{C} \pm 1{ }^{\circ} \mathrm{C} / 75-85 \%$ $\mathrm{RH}$ and evaluated 10 days after, and under refrigeration $\left(3^{\circ} \mathrm{C} \pm 1^{\circ} \mathrm{C} / 90-95 \% \mathrm{RH}\right)$ for 21 days and after that transferred to room condition for 5 days, when the evaluation was performed.

The effect of chitosan at $2 \%$ (purchased from Sigma ${ }^{\circledR}$ ) diluted in citric acid $(1 \mathrm{M})$ and of the citric acid alone was also evaluated for the control of black spot disease. Fruits were stored at room condition and evaluated after 12 days. The experimental design was completely randomised with 40 replications. The results were transformed in $\sqrt{x}+0.5$ and compared by Tukey test $(P=0.05)$.

\section{Biochemical analyses}

Citrus fruit skin $(\approx 1 \mathrm{~g})$ was obtained at different time intervals after treatment $(0,24,48$, and $72 \mathrm{~h})$, and mechanically homogenized in a mortar with 4 $\mathrm{ml}$ acetate buffer $(100 \mathrm{mM}, \mathrm{pH} 5.0)$. Then, the extract was centrifuged $(20,000 \mathrm{~g} / 25 \mathrm{~min}$, at $4^{\circ} \mathrm{C}$ ), and the supernatant was collected and used for enzyme activity and protein determination.

Chitinase activity was evaluated by measuring the release of soluble fragments from carboxymethylated chitin labelled with remazol blight violet (CM-chitin-RBV) (Wirth and Wolf, 1992). For this, $40 \mu \mathrm{L}$ of protein extract was added to $810 \mu \mathrm{L}$ of the same extraction buffer and 150 $\mu \mathrm{L}$ of CM-chitin-RBV $\left(2 \mathrm{mg} \mathrm{mL}^{-1}\right)$. After $20 \mathrm{~min}$ incubation at $40^{\circ} \mathrm{C}$ in water bath, the reaction was stopped by adding $200 \mu \mathrm{L}$ of $1.0 \mathrm{M} \mathrm{HCl}$. The samples were maintained in refrigerator $\left(\approx 10^{\circ} \mathrm{C}\right)$ for $10 \mathrm{~min}$, followed by centrifugation at 10,000 $\mathrm{g} / 5 \mathrm{~min}$. The absorbance at $550 \mathrm{~nm}$ was determined having the extraction buffer as reference. The results were express as specific activity (absorbance units $\mathrm{min}^{-1} \mathrm{mg}$ protein ${ }^{-1}$ ).

$\beta$-1,3-glucanase activity was evaluated by measuring the release of soluble fragments of carboxymethylated curdlan labelled with remazol blight blue (CM-curdlan-RBB). For this, $40 \mu \mathrm{L}$ of protein extract was added to $760 \mu \mathrm{L}$ of the same extraction buffer and $200 \mu \mathrm{L}$ of "CM-curdlanRBB" (4 mg mL $\left.{ }^{-1}\right)$. After $20 \mathrm{~min}$ incubation at $40^{\circ} \mathrm{C}$ in water bath, the reaction was stopped by adding $200 \mu \mathrm{L}$ of $1.0 \mathrm{M} \mathrm{HCl}$. The samples were maintained in refrigerator $\left(\approx 10^{\circ} \mathrm{C}\right)$ for $10 \mathrm{~min}$, followed by centrifugation at $10,000 \mathrm{~g} / 5 \mathrm{~min}$. The absorbance at $600 \mathrm{~nm}$ was determined having the extraction buffer as reference. The results were expressed as specific activity (absorbance units $\min ^{-1} \mathrm{mg} \operatorname{protein}^{-1}$ ).

Peroxidase activity was evaluated by measuring the conversion of guaiacol in tetraguaiacol in a spectrophotometer at $470 \mathrm{~nm}$ (Lusso and Pascholati, 1999). The mixture of reaction contained $25 \mu \mathrm{L}$ of protein extract and $2.97 \mathrm{~mL}$ of a solution containing $250 \mu \mathrm{L}$ of guaiacol and 306 $\mu \mathrm{L}$ of hydrogen peroxide in $100 \mathrm{ml}$ of $0.01 \mathrm{M}$ phosphate buffer ( $\mathrm{pH}$ 6.0). The reference was a 3 $\mathrm{mL}$ solution containing $250 \mu \mathrm{L}$ of guaiacol and $306 \mu \mathrm{L}$ of hydrogen peroxide in $100 \mathrm{~mL}$ of $0.01 \mathrm{M}$ phosphate buffer. Peroxidase activity was expressed as specific activity (absorbance units $\min ^{-1} \mathrm{mg}$ protein ${ }^{-1}$ ).

Polyphenoloxidase activity was determinate by measuring the conversion of cathecol to quinone, mediated by polyphenoloxidase (Duangmal and Apenten, 1999). Cathecol (20 mM) was dissolved in $100 \mathrm{mM}$ sodium-phosphate buffer $(\mathrm{pH} 6,8)$. Protein extract $(100 \mu \mathrm{L})$ was mixed in $900 \mu \mathrm{L}$ of substrate and absorbance was determined at 420 $\mathrm{nm}$ for $2 \mathrm{~min}$. Results were expressed as specific activity (absorbance unit $\mathrm{min}^{-1} \mathrm{mg}$ protein ${ }^{-1}$ ).

\section{RESULTS AND DISCUSSION}

\section{In vitro effect of chitosan on G. citricarpa development}

Mycelial growth of G. citricarpa was completely inhibited by all chitosan concentrations during the incubation period (Fig. 1A). Chitosan $1 \%$ and citric acid $2 \%$ completely inhibited the mycelial growth, while the fungicide thiabendazole inhibited, but not completely (Fig. 1B). The total inhibition caused by citric acid could be due the low $\mathrm{pH}$ of the medium. Bautista-Baños et al. (2003) reported that chitosan completely inhibited Colletotrichum gloeoporioides mycelial growth at 2.5 and $3.0 \%$. At 0.5 and $1.5 \%$, the growth started 
after 2 and 4 days of incubation, respectively, and stopped after 4 and 6 days, respectively.

Conidial germination and apressorium formation of $G$. citricarpa were stimulated by chitosan when compared to control (Fig. 2). However, the conidial germination and apressorium formation were irregular, with both germ tube and apressorium deformed (data not shown). Plascencia-Jatomea et al. (2003) showed that chitosan caused spore aggregation and morphological anomalies affecting the swelling, germ tube and spores polarization of Aspergillus niger.

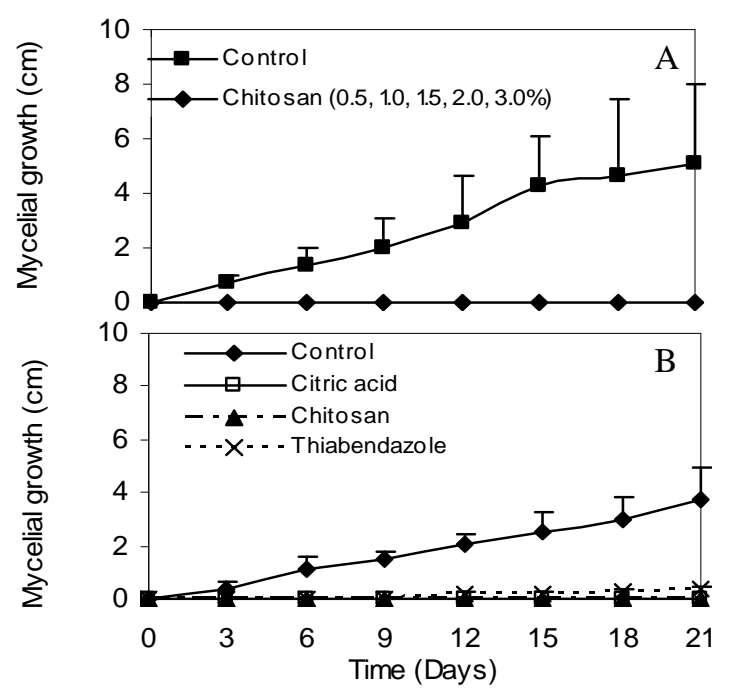

Figure 1 - Effect of chitosan in various concentrations (A) and chitosan 1\%, citric acid 2\%, thiabendazole $200 \mu \mathrm{L} \mathrm{L}^{-1}$ (B) on in vitro mycelial growth of Guignardia citricarpa. Control is represented by PDA culture medium without chitosan. Bars represent mean \pm SD.

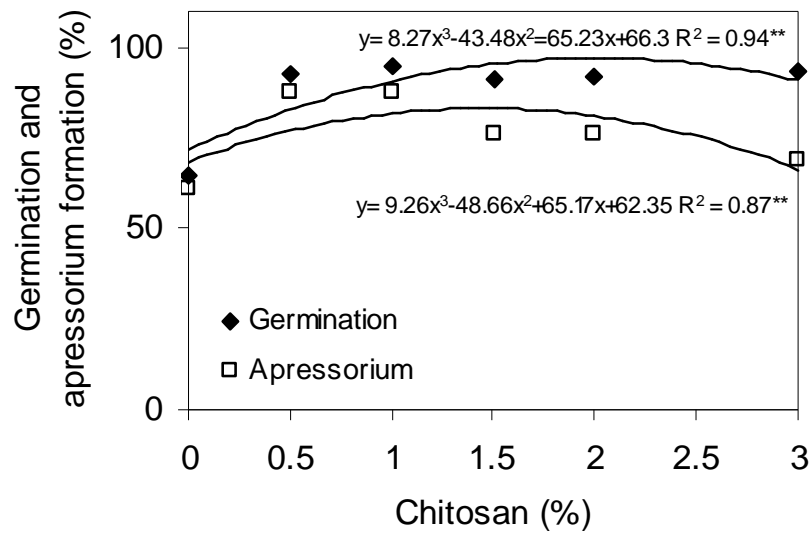

Figure 2 - In vitro effect of chitosan in different concentrations on germination and apressorium formation by Guignardia citricarpa.

$* *$ Significant at $1 \%$ of probability. 
In vivo effect of chitosan in controlling black spot

It was observed that until the $2^{\text {nd }}$ day of storage the chitosan did not reduce the lesions development. However, after the $6^{\text {th }}$ day of evaluation, the chitosan at $0.5,1.0,1.5$, and $2 \%$ was effective in inhibiting new lesions development (Fig. 3), and did not show phytotoxicity to 'Valencia' oranges.

At room condition (Fig.4A) and under refrigeration (Fig. 4B), chitosan alone or with thiabendazole reduced the formation of new lesions of black spot. However, thiabendazole alone did not reduce it in oranges kept under refrigeration (Fig. 4B). Chien et al. (2006) reported that a $0.1 \%$ low molecular weight chitosan coating substantially slowed the decay of Murcott tangor stored at $15^{\circ} \mathrm{C}$ in relation to a control treatment and reduced decay by over $20 \%$ as compared to the fungicide thiabendazole.

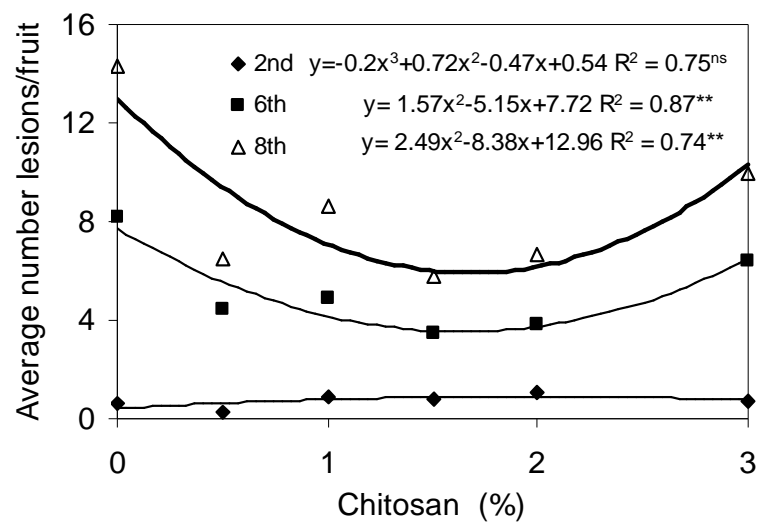

Figure 3 - Effect of chitosan on black spot in 'Valencia' oranges stored at $25^{\circ} \mathrm{C} \pm 1^{\circ} \mathrm{C} / 75-85 \% \mathrm{RH}$ and evaluated at $2^{\text {nd }}, 6^{\text {th }}$ and $8^{\text {th }}$ days after treatment.

**Significant at $1 \%$ of probability; ${ }^{\text {ns }}$ Not significant.

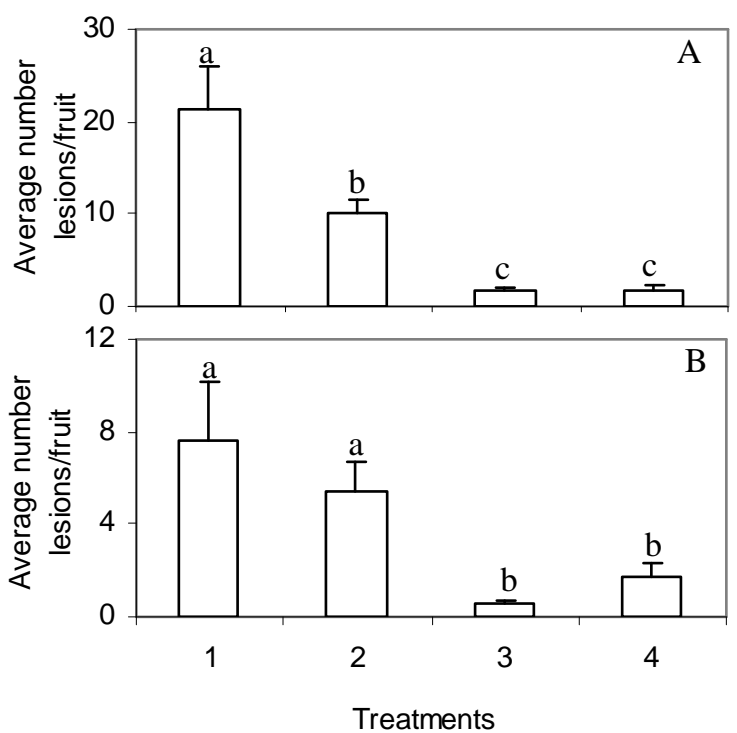

Figure 4 - Effect of chitosan and thiabendazole on black spot in 'Valencia' oranges. (A) Stored at $25^{\circ} \mathrm{C} \pm 1^{\circ} \mathrm{C} / 75-85 \% \mathrm{RH}$ and evaluated 10 days after treatment. (B) Stored at $3^{\circ} \mathrm{C} \pm 1^{\circ} \mathrm{C} / 90$ $95 \%$ RH for 21 days and transferred to room condition for 5 days, then evaluated. Results transformed to $\sqrt{ }(x+0,5)$. Values with the same letters are not statistically different $(P=0.05)$ and the bars are the means \pm SE. Treatments: 1- Control; 2- Thiabendazole (480 g a.i. $100 \mathrm{~L}^{-1}$ ); 3- Chitosan 2\%; 4- Thiabendazole + Chitosan. 
The storage of citrus under refrigeration contributes for reduction of black spot disease. Refrigeration is the main physical method to prolong the postharvest life of fruits and inhibit or delay the pathogens development (Benato et al., 2001).

These results showed that chitosan could contribute for the reduction of black spot disease in 'Valencia' oranges. Some studies showed that chitosan controlled postharvest diseases in bell pepper, papaya, apple, lemon, and oranges (El Ghaouth et al., 1994, Bautista-Baños et al. 2003; El Ghaouth et al., 2000).
When compared to citric acid or control treatments, only the chitosan, diluted in citric acid, reduced the development of black spots (Fig. 5). El Ghaouth et al. (1997) reported that chitosan might have prevented the maceration of bell pepper tissue by $B$. cinerea, because not only was effective in reducing the production of polygalacturonases by fungus, but also caused severe cytological damage to invading hyphae. This could, in part, explain the limited ability of the pathogen to colonize tissues in the presence of chitosan.

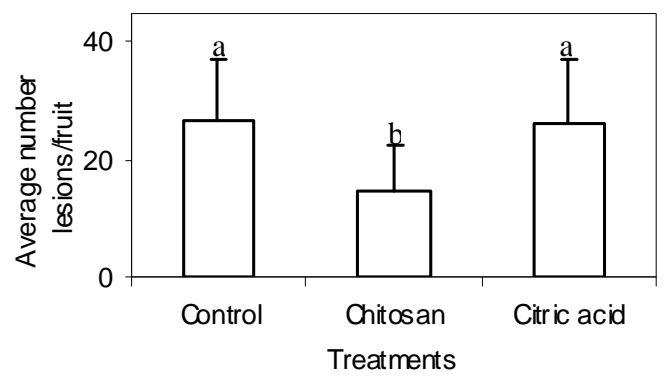

Figure 5 - Effect of chitosan and citric acid on black spot in 'Valencia' oranges stored at $25^{\circ} \mathrm{C} \pm 1^{\circ} \mathrm{C} / 75-85 \% \mathrm{RH}$, and evaluated 12 days after treatment. Results transformed to $\sqrt{ }(\mathrm{x}+0,5)$. Values with the same letters are not statistically different $(P=0.05)$ and bars are the means $\pm \mathrm{SE}$.

\section{Biochemical analyses}

The increase in the activity of chitinase, $\beta-1,3-$ glucanase, polyphenoloxidase, and peroxidase was demonstrated as result of chitosan application in 'Valencia' oranges, $24 \mathrm{~h}$ after chitosan treatment (Fig. 6). This change in enzyme activity can contribute for the reduction of black spots, since these enzymes are involved in defence responses against pathogens. The induction of defence enzymes in fruit tissues by chitosan can be important in delaying the development of quiescent infections that, typically, become active when the tissue resistance declines.

Ballester et al. (2006) reported that peroxidases and phenylalanine ammonia-liase showed higher activity in flavedo that was more resistant to
Penicillium digitatum development. The participation of $\beta$-1,3-glucanase in flavedo in the defence of citrus fruit against $P$. digitatum has also been shown (Fajardo et al., 1998; Porat et al, 2001). El Ghaouth et al. (1994) attributed the inhibitory effect of chitosan to the combination of antifungal activity and resistance responses. Chitosan elicited peroxidase activity and lignin accumulation in wheat leaves, chitosanase in bell peppers and chitinase and peroxidase in cucumber (Vander et al., 1998; El Ghaouth et al., 1994; BenShalom, 2003). Thus, the protective effect of chitosan in 'Valencia' oranges seems to be a combination of the antifungal property and of the ability of the product in inducing defence responses in fruits. 


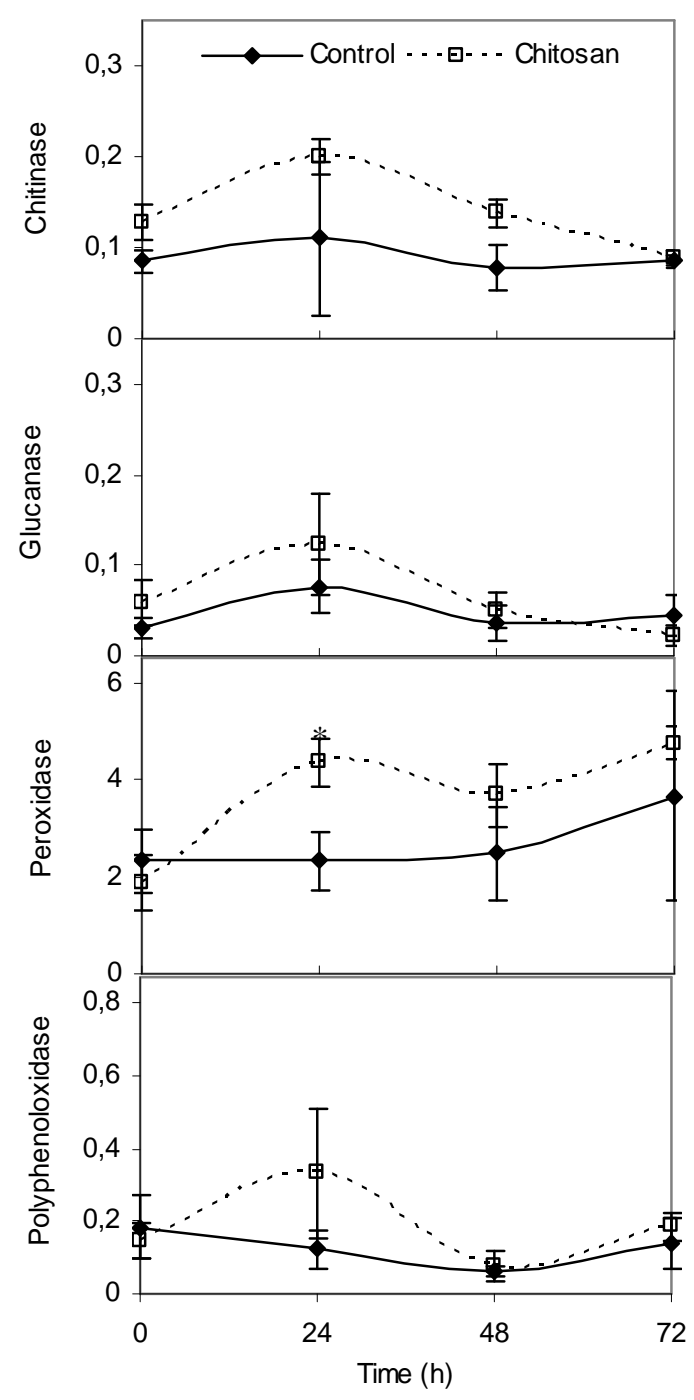

Figure 6 - Chitinase, $\beta$-1,3-glucanase, peroxidase, and polyphenoloxidase activities in 'Valencia' orange skin treated with chitosan. Enzyme activity expressed as UAbs $\min ^{-1} \mathrm{mg}$ protein $^{-1}$. Bars represent means $\pm \mathrm{SE}$.

*Statistically different $(P=0.05)$.

\section{CONCLUSION}

Chitosan exhibited in vitro antifungal effects on Guignardia citricarpa and potential to control the development of black spot lesions on 'Valencia' postharvest oranges, stimulating defence responses in citrus skin.

\section{ACKNOWLEDGEMENTS}

The authors thank FAPESP and CNPq for the financial support.

\section{RESUMO}

Frutos cítricos são afetados pela mancha preta dos citros, causada por Guignardia citricarpa. A indução de resistência é uma alternativa de controle e a quitosana exibe potencial como indutor de resistência. $\mathrm{O}$ efeito da quitosana sobre G. citricarpa foi avaliado in vitro e em laranjas 'Valência'. Frutos cítricos foram imersos em diferentes concentrações de quitosana. Quitosana (2\%), associada ou não com tiabendazol e ácido cítrico, foi também avaliada. Todas as concentrações de quitosana inibiram o crescimento 
micelial de G. citricarpa e afetaram morfologicamente a germinação dos conídios e a formação de apressórios. Quitosana inibiu o desenvolvimento de novas lesões em laranjas em condições ambiente e sob refrigeração. Tiabendazol e ácido cítrico não reduziram o aparecimento de novas lesões. Análises bioquímicas revelaram que atividades de quitinase, $\beta$-1,3-glucanase, peroxidase e polifenoloxidase aumentaram em frutos tratados com quitosana. Portanto, a capacidade da quitosana na redução da mancha preta em laranja 'Valência' pode ser devida ao efeito germicida sobre o patógeno e/ou a indução de resistência no tecido do fruto.

\section{REFERENCES}

Ballester, A.R., Lafuente, M.T., and GonzálesCandelas, L. (2006), Spatial study of antioxidant enzymes, peroxidase and phenylalanine ammonialyase in the citrus fruit-Penicillium digitatum interaction. Postharvest Biology and Techology, 39, 115-124.

Bautista-Baños, S., Hernández-López, M., BosquezMolina, E., and Wilson, C.L. (2003), Effects of chitosan and plant extracts on growth of Colletotrichum gloeosporioides, anthracnose levels and quality of papaya fruit. Crop Protection, 22, 1087-1092.

Benato, E.A., Cia, P., and Souza, N.L. (2001), Manejo de doenças de frutas pós-colheita. Revisão Anual de Patologia de Plantas, 9, 403-441.

Ben-Shalom, N., Ardi, R., Pinto, R., Aki, C., and Fallik, E. (2003), Controlling grey mould caused by Botrytis cinerea in cucumber plants by means of chitosan. Crop Protection, 22, 285-290.

Camili, E.C. (2004), Avaliação de agentes bióticos e abióticos aplicados em pós-colheita na proteção de uva 'Itália' contra Botrytis cinerea. MsC Thesis, Faculdade de Ciências Agronômicas, Universidade Estadual Paulista, Botucatu, São Paulo, Brazil.

Chien, P.J., Sheu, F., and Lin, H.R. (2007), Coating citrus (Murcott turgor) fruit with low molecular weight chitosan increases postharvest quality and shelf life. Food Chemistry, 100, 1160-1164.

Duangmal, K. and Apenten, R.K.O. (1999), A comparative study of polyphenoloxidases from taro (Colocasia esculenta) and potato (Solanum tuberosum var. Romano). Food Chemistry, 64, 351359.
El Ghaouth, A., Arul, J., Grenier, J., and Asselin, A. (1992), Antifungal activity of chitosan on two postharvest pathogens of strawberry fruits. Phytopathology, 82, 398-402.

El Ghaouth, A., Arul, J., Wilson, C., and Benhamou, N. (1994), Ultrastructural and cytochemical aspects of the effect of chitosan on decay of bell pepper fruit. Physiological and Molecular Plant Pathology, 44, 417-432.

El Ghaouth, A., Arul, J., Charles, W., and Benhamou, N. (1997), Biochemical and cytochemical aspects of the interactions of chitosan and Botrytis cinerea in bell peper fruit. Postharvest Biology and Technology, 12, 183-194.

El Ghaouth, A., Smilanick, J.L., and Wilson, C. (2000), Enhancement of the performance of Candida saitoana by the addition of glycolchitosan for the control of postharvest decay of apple and citrus fruit. Postharvest Biology and Technology, 19, 103-110.

Fajardo, J.E., McCollum, T.G., McDonald, R.E., and Mayer, R.T. (1998), Differential induction of proteins in orange flavedo by biologically based elicitors and challenged by Penicillium digitatum Sacc. Biological Control, 13, 43-151.

Fischer, I.H., Spósito, M.B., Lourenço, S.A., and Amorin, L. (2004), Eficiência dos fungicidas thiabendazole + imazalil, aplicados previamente ou em mistura à cera, no controle do bolor verde em citros. Brazilian Journal of Plant Physiology, 16, 22 (S).

Góes, A. (2001), A mancha preta dos frutos cítricos causada por Guignardia citricarpa. Fitopatologia Brasileira, 26, 245-246 (S).

Hammerschmidt, H. and Dann, E.K. (1997), Induced resistance to disease. In - Environmentally Safe Approaches to Crop Disease Control, eds. Rechcigl, N.A. and Rechcigl, J.E. CRC Press, Boca Raton, p.177-199.

Lusso, M.F.G. and Pascholati, S.F. (1999), Activity and isoenzymatic pattern of soluble peroxidases in maize tissues after mechanical injury or fungal inoculation. Summa Phytopathologica, 25, 244-249.

Pascholati, S.F. and Leite, B. (1995), Hospedeiro: mecanismo de resistência. In - Manual de Fitopatologia: Princípios e Conceitos, eds. Bergamin Filho, A., Kimati, H., and Amorim, L. Editora Agronômica Ceres, São Paulo, p.417-453.

Plascencia-Jatomea, M., Viniegra, G., Olayo, R., Castillo-Ortega, M.M., and Shirai, K. (2003), Effect of chitosan and temperature on spore germination of Aspergillus niger. Macromolecular Bioscience, 3, 582-586. 
Porat, R., Vinokur, V., Holland, D., McCollum, G. and Droby, S. (2001), Isolation of a citrus chitinase cDNA and characterization of its expression in response to elicitation of fruit pathogen resistance. Plant Physiology, 158, 1585-1590.

Reis, R.F., Timmer, L.W., and Góes, A. (2006), Effect of temperature, leaf wetness, and rainfall on the production of Guignardia citricarpa ascospores and on black spot severity on sweet orange. Fitopatologia Brasileira, 31, 29-34.

Terry, L.A. and Joyce, D.C. (2004), Elicitors of induced disease resistance in postharvest horticultural crops: a brief review. Postharvest Biology and Technology, 32, 1-13.

Vander, P., Kjell, M.V., Domard, A., El Gueddari, N.E., and Moerschbacher, B.M. (1998), Comparison of the ability of partially $\mathrm{N}$-acetylated chitosans and oligosaccharides to elicity resistance in wheat leaves. Plant Physiology, 118, 1353-1359.
Van-Loon, L.C. and Van-Strien, E.A. (1999), The families of pathogenesis-related proteins, their activities, and comparative analysis of PR-1 type proteins. Physiological and Molecular Plant Pathology, 55, 85-97.

Wirth, S.J. and Wolf, G.A. (1992), Micro-plate colorimetric assay for endo-acting cellulose, xylanase chitinase, 1,3- $\beta$-glucanase and amylase extracted from forest soil horizons. Soil Biology and Biochemistry, 24, 511-519.

Received: November 28, 2006; Revised: August 31, 2007; Accepted: July 18, 2008. 